\title{
SYMPTOMATIC HYPONATREMIA FOLLOWING NITROPRUSSIDE THERAPY
}

by

Nasim Ashraf, M.D.*

Renal Fellow

and

William J.C. Amend, Jr., M.D., F.A.C.P.+

DOI: http://dx.doi.org/10.5915/14-3-12139

\section{INTRODUCTION}

Sodium nitroprusside has proved to be a reliable and effective agent for acutely lowering blood pressure in hypertensive crises. ${ }^{1}, 2$ Given this agent's profound circulatory effects, it is possible that altered sodium and water handling might result with its use. We report a patient who developed acute symptomatic hyponatremia following intravenous nitroprusside infusion on two consecutive occasions for control of accelerated hypertension.

\section{CASE SUMMARY}

This was a 63 year old female with a 20 -year history of hypertension who presented to an outside hospital with headaches, right-sided abdominal pain, nausea and vomiting. She had been in her usual state of health with reasonable control of blood pressure receiving Combipres $0.3 \mathrm{mg}$ /daily until one week prior to admission when her symptoms began. On admission. her blood pressure was noted to be $240 / 130$. Physical examination was essentially unremarkable except for marked arteriolar narrowing of retinal vessels and mild epigastric tenderness. There were no neurological deficits nor any signs of heart failure. Admission laboratoy data revealed a hematocrit of $45 \%$ with serum sodium $132 \mathrm{mEq} / \mathrm{l}$, serum potassium 2.7 $\mathrm{mEq} / 1$, serum chloride $100 \mathrm{mEq} / \mathrm{l}$ and serum bicarbonate of $24 \mathrm{mEq} / 1$. A BUN and creatinine were within normal limits with a urine specific gravity of 1.012. The remainder of her general blood chemistry panel was essentially normal. The chest $x$-ray showed a normal size cardiac silhouette with no evidence of active cardiopulmonary disease. The electrocardiogram was unremarkable. She was started on continuous sodium nitroprusside infusion at 3-4 $\mathrm{mcg} / \mathrm{Kg} / \mathrm{min}$ which resulted in a prompt lowering of her blood pressure from $240 / 130$ to $150 / 90$ in the first twelve hours. During the first 72 -hour period, the serum sodium dropped from $133 \mathrm{mEq} / 110119 \mathrm{mEq} / \mathrm{I}$ (see figure 1. period 1) with the patient becoming confused and less responsive. Fluid restriction was enforced with a correction of her serum sodium to 132 $\mathrm{mEq} / \mathrm{I}$ over the next few days. Because of an inability to wean the patient off her nitroprusside infusion, she was transferred to our hospital on the seventeenth hospital day.

On admission to UCSF, the blood pressure was $200 / 100$ with the patient having been off the nitroprusside infusion for approximately eight hours. Fresh hemorrhages were seen on funduscopy with an otherwise unremarkable physical examination. The serum sodium was $133 \mathrm{mEq} / \mathrm{I}$, potassiu, 2.9, chloride 89 , and a total bicarbonate $29 \mathrm{mEq} / 1$. The BUN was $11 \mathrm{mg} \%$ with a serum creatinine of $0.9 \mathrm{mg} \%$. The admission SMA-12 was within normal limits and the chest $\mathrm{x}$-ray and the electrocardiogram were similarly unremarkable. Thyroid and adrenal functions were normal. Two twenty-four hour VMA tests were normal. The patient was restarted on a continuous nitroprusside infusion at $3-4 \mathrm{mcg} / \mathrm{Kg} / \mathrm{min}$. Over the next 72 hours, the serum sodium again fell from 133 $\mathrm{mEq} / \mathrm{I}$ to $119 \mathrm{mEq} / \mathrm{I}$ (figure I, period 11 ) with her blood pressure dropping to $100 / 70$ at the lowest. The patient again became disoriented, confused and complained of headaches. Hypertonic sodium chloride $(5 / 4 \mathrm{mM})$ infusion was immediately begun with a correction of the serum sodium to $132 \mathrm{mEq} / 1$ over the next 36 hours. Her neurologic symptoms ameliorated. Over the next three to four days, a satisfactory control of blood pressure was achieved with oral medications which included Inderal, Dibenzyline and Hydralazine. The nitroprusside was eventually discontinued. No further hyponatremia was noted despite a later period of a positive fluid balance.

+ Associate Clinical Professor of Medicine, Renal Transplant Service, University of California, San Francisco, $\mathrm{Ca}$.

* Reprints Requests: William J. Amend, Jr., M.D., University of California, Room 884, Moffitt Hospital, San Francisco, California 94143. 


\section{DISCUSSION}

The development of severe. symptomatic hyponatremia was temporarily associated with two consecutive administrations of nitroprusside. This occurred concomitantly with acute reductions in systemic blood pressure. There were no clinical signs of dehydration or, alternatively, of congestive heart failure. A temporary drug-induced sequence which led to an impaired ability to handle a water load is evidence by: (1) a net positive fluid balance on both occasions, (2) the consecutive hyponatremic episodes following nitroprusside, (3) the low-measured urinary sodiums (ruling out renal salt-wasting), and (4) a restoration of renal diluting capability once the nitroprusside had been discontinued. The renal function remained normal throughout the observation.

It is now well recognized that $\mathrm{ADH}$ release may be influenced by osmotic and non-osmotic stimuli. ${ }^{3}$ Left atrial receptors, which are low-pressure receptors, modulate ADH-release through the vagus nerve. Shu ayb demonstrated a significant increase in plasma ADH levels following release of distended left atrial balloons in dogs. ${ }^{4}$ This was associated with a reduction in urine flow and could be abolished by vagotomy. D'Angelo, in a review of water and electrolyte disturbances which follow mitral cimmissurotomy, described five patients who developed dilutional hypernatremia with serum sodiums falling between 7 $20 \mathrm{mEq} /$ l. $^{5}$ This dilutional hyponatremia was associated with post operative oliguria after correction of long standing mitral stenosis.
Since the major hemodynamic changes induced by nitroprusside ${ }^{6}$ are reflected by a fall of arterial pressure, a decrease in left atrial and left ventricular pressure with a rise in cardiac output, it is conceivable that sodium nitroprusside infusion in this individual, with markedly elevated arterial pressures, produced a potent non-osmotic stimulus for ADH release by acutely lowering left atrial pressure relieving left atrial distension. The dilutional hyponatremia occurring in our case following nitroprusside administration on two occasions might have had as its cause a mechanism similar to that of the post commissurotomy syndrome.

\section{REFERENCES}

1. Gifford. Ray W.. Ir.: The treatment of hypertensive emergencies. Amer. J. Cardiol. 9:880-887, 1962.

2. Palmer. R.F. and Lasseter, K.C.: Sodium Nitroprusside. N. Eng. J. of Med, 292:294-296, 1975.

3. Schrier, R.W.. Berl, T, and Anderson, R.J.: Osmotic and non-osmotic control of vasopressin release. $A m . J$. Physiol. 236:321-332, 1979.

4. Shuayb. W.A.. Moran, W.H. and Zimmerman, B.: Studies of the mechanism of antidiuretic hormone secretion and the post-commisurotomy dilutional syndrome. Ann. Surg. 162:690-701, 1961.

5. D'Angelo. G.J.. Murdaugh, H.V.. and Sealy, W.C.: The nature and treatment of the post-commissurotomy hyponatremic syndrome, Surg. Gynec. and Obster. 106: $87-93,1958$.

6. Cohn, J.N. and Burke, L.P.: Nitroprusside. Ann. Im. Med. 91:752-757, 1979.

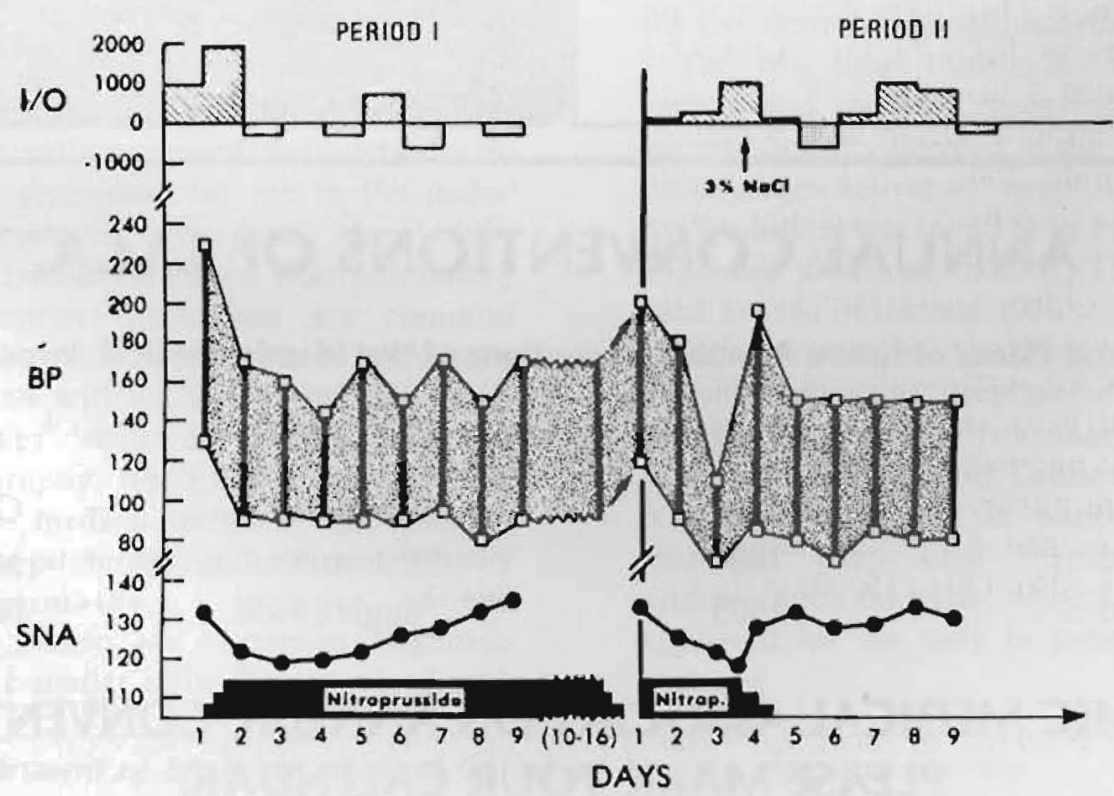

The Journal of IMA - Vol. 14 - July 1982 - Page 79 